\title{
The Development of Big Book Media as a Local Solution for the Student Literacy Movement of Inpres Sambori Elementary School Lambitu District Bima Regency
}

\author{
Nunung Fatimah* \\ STKIP Taman Siswa Bima \\ Bima, Indonesia \\ nunungfatimah95@gmail.com
}

\author{
Desy Ningsih Komalasari \\ STKIP Taman Siswa Bima \\ Bima, Indonesia
}

\begin{abstract}
Developing mother tongue Big Book media for students is very essential for their habits of using their mother tongue in learning. With the presence of the media, the students can collaborate with each other and, at the same time, with the big mother tongue media, they can pay more attention to lerning eventhough their literacy interest is low. This study aims to produce a mother tongue big book media product to improve children's literacy movements using the development method with research steps to detect potential problems, data collection, product design, design validation, design revision, product testing, product revision, trial usage, product revisions, and mass products. The research sample of students, data collection techniques using the observation sheet. The results of this study indicate that the Development of Mother Language Big Book Media as a Local Solution for Increasing the Student Literacy Movement at Inpres Sambori Elementary School, Lambitu District, Bima Regency has passed the product evaluation stage, both limited feasibility tests of content experts, language and graphic experts, as well as product trials. including initial field tests, main field tests, and expanded field tests. The results of the development of the big book media products are feasible to become final products that can be practiced to increase students' reading interest. The findings in this study reveal that the literacy learning process using the mother tongue big book media greatly facilitates students in understanding literacy materials as it is fun, interesting, motivating to students, and activating to them in learning.
\end{abstract}

Keywords-development, big book media, literacy

\section{INTRODUCTION}

Literacy is the ability to read and write so that the development of literacy should be very importantly paid attention to properly and literacy is the initial skill that everyone must have. With the presence of literacy, students even at early grades will be able to read [1]. One solution to improving students' reading and writing skills is through the development media Big Book of mother tongue, which is a local solution to increasing the student literacy movement at SDN Inpres Sambori, Lambitu District, Bima Regency. Students at SDN Inpres Sambori still have problems with the ability to read and write. Learning media called Big book can be a solution and it is media in the form of reading books that are presented in large-size formats and equipped with large texts and pictures and these large sizes are expected to be able to make the children more active in reading and even writing.

This project is done within the literacy movement framework. The literacy movement is the ability to access, understand, and use something intelligently through various activities, including reading, seeing, listening, writing, and speaking [2]. The stages of implementing the literacy movement include growing interest in reading through 15 minutes of reading activities, increasing literacy skills through activities to respond to enrichment books, and increasing literacy skills in all subjects using enrichment books and reading strategies in all subjects. With this problem, it is necessary to have proper handling so that students' reading interest in literacy will increase and in this way teachers must be able to create the right strategy so that children are not bored and lazy in participating in literacy activities. In innitial observations, we have found at Inpres Sambori Elementary School, Lambitu District, Bima Regency that the average reading interest of children is very low/low so that the presence of this media big book will be able to activate the children in reading and writing actvities.

A big book (Buku Besar) is a reading book that has large size. The big book has special characteristics that are enlarged, both in texts and in images that the $\backslash$ children could enjoy reading it. In this media big book, the teacher can choose the contents of the story and the topic according to the interests of the children or according to what the theme that they want to read (Workshop on Material Workshop for Good Practice SD/MI Schools, February 2015). According to USAID [3], learning media big book is media in the form of reading books that are presented in large formats and are equipped with large texts and pictures. Big books come in various sizes, for example, A3, A4, A5, or the size of a newspaper. The size is adjusted to the legibility aspect of all students in the class. Suyanto [1] explains that big book learning media is enjoybale to children and eacy to be made by teachers.

The media big book contains short stories in large written and image formats to attract attention and arouse students' enthusiasm for reading. Because with the increasing enthusiasm and interest in reading children, these students will more easily understand the material to be read [4] media is Big book made with a special purpose, pedagogical goals. media Big book has the following objectives: providing 
reading experience, introducing various reading sources to students, allowing teachers to provide examples of good reading, making it easier for students to understand reading content, involving students to participate in active and participatory learning, to provide various examples of reading suitable for use in learning, and as a source of information. The following are the stages of making media big book: (1) prepare paper at least A3 size totaling 8-10 pages, colored markers, glue, and HVS paper, (2) choose a story theme, (3) develop the story topic into a complete story that is adjusted to the level or class level, (4) writing sentences on the HVS paper by cutting the HVS paper into several parts then writing the sentence with a large marker according to the correct rules, (5) pasting the writing of each sentence on the planned page, (6) preparing a picture interesting according to the contents of the story on each page, (7) determine the title that is appropriate to the big book media.

The novelty form of scientific works in this writing with other scientific works is in the development of the media so that it is not only portraying and writing in Indonesian, but there are pictures and a new local language in Indonesian that distinguishes it from other works. Based on the description of the background above, the basis for the formulation of the problem in this study is how the development of big book media the mother tongue can help increase the literacy movement of students at Inpres Sambori Elementary School, Lambitu District, Bima Regency. The purpose of this study was to produce a media product big book mother tongue that would assist students in improving the literacy movement at Inpres Sambori Elementary School, Lambitu District, Bima Regency.

Development can be a process, product, and research design. Development is a process used to develop and validate educational products. The purpose of development research is to assess the changes that have occurred over some time [5]. In this development research, the development product produced is in the form of Big Book Media in Mother Language, the product produced in this media has its own uniqueness, because big book media is not like other media, on the other hand, this media refers more to the story that has translation mother tongue or first language which is the language Bima generated in this development will provide challenges for those who read, and also allows students who specifically low-class.

\section{METHODS}

Developing mother tongue-based Big Book media is a local solution to increase literacy skill in the movements and Borg and Gall's [6] model of Research and Development (R\&D) research is used. This research is a developmental study. We will invent the big book media as interestingly as possible with various efforts so that the book can be visible to the students. The study was carried out at Inpres Sambori Elementary School, Lambitu District, Bima Regency. This data were analyzed with various groupings of information from the data collected in the form of needs questionnaire, interviews, and trial questionnaires. The needs questionnaire is shown to students and teachers in the hope of knowing development needs. Qualitative data analysis will be obtained in descriptive qualitative development research, while in quantitative data analysis obtained in quantitative development research. Borg and Gall's Research and Development (R\&D) was used and these steps were fllowede: identification of potential problems, data collection, product design, design validation, design revision, product testing, product revision, use trial, product revision, and mass production.

\section{RESULTS AND DISCUSSION}

\section{Development Stages}

\section{Needs Analysis}

Needs analysis were carried out with teachers of Inpres Sambori Elementary School, Lambitu Pertama, a questionnaire to identify the teacher's needs was filled out by one of the teachers. This teacher needs questionnaire contains 10 statements which aim to find out the teacher's needs about the big book media used for literacy activities in schools before the developer develops a product in the form of a mother tongue big book media. The data from the analysis of teacher needs can be seen in the Table I.

TABLE I. DATA ANALYSIS OF TEACHER NEEDS

\begin{tabular}{|c|c|c|c|c|c|}
\hline \multirow[t]{2}{*}{ NO } & \multirow[t]{2}{*}{ Questions } & \multicolumn{4}{|c|}{ Category } \\
\hline & & $\begin{array}{l}\text { strongly } \\
\text { agree }\end{array}$ & $\begin{array}{l}\text { Agre } \\
\text { e }\end{array}$ & $\begin{array}{l}\text { disa } \\
\text { gree }\end{array}$ & $\begin{array}{l}\text { disag } \\
\text { ree } \\
\text { less }\end{array}$ \\
\hline 1. & $\begin{array}{l}\text { Are you happy with } \\
\text { the big book in your } \\
\text { mother tongue? }\end{array}$ & $100 \%$ & $0 \%$ & $0 \%$ & $0 \%$ \\
\hline 2. & $\begin{array}{l}\text { Do you often design } \\
\text { or develop big book } \\
\text { media? }\end{array}$ & $0 \%$ & $\begin{array}{l}100 \\
\%\end{array}$ & $0 \%$ & $0 \%$ \\
\hline 3. & $\begin{array}{l}\text { Does every school } \\
\text { have a big book } \\
\text { media?? }\end{array}$ & $100 \%$ & $0 \%$ & $0 \%$ & $0 \%$ \\
\hline 4. & $\begin{array}{l}\text { The mother tongue } \\
\text { big book media is a } \\
\text { learning resource } \\
\text { that makes it easier } \\
\text { for students to } \\
\text { understand the } \\
\text { contents of the } \\
\text { reading in the story. }\end{array}$ & $100 \%$ & $0 \%$ & $0 \%$ & $0 \%$ \\
\hline 5. & $\begin{array}{l}\text { The mother tongue } \\
\text { big book media was } \\
\text { developed to support } \\
\text { the literacy } \\
\text { movement. }\end{array}$ & $0 \%$ & $\begin{array}{l}100 \\
\%\end{array}$ & $0 \%$ & $0 \%$ \\
\hline 6. & $\begin{array}{l}\text { The development of } \\
\text { Indonesian language } \\
\text { learning in the big } \\
\text { book media }\end{array}$ & $0 \%$ & $\begin{array}{l}100 \\
\%\end{array}$ & $0 \%$ & $0 \%$ \\
\hline 7. & $\begin{array}{l}\text { The big book media } \\
\text { is really needed by } \\
\text { students } \\
\text { activities to support } \\
\text { the literacy } \\
\text { movement. }\end{array}$ & $100 \%$ & $0 \%$ & $0 \%$ & $0 \%$ \\
\hline 8. & $\begin{array}{l}\text { Big book media is } \\
\text { presented in the } \\
\text { form of a story book }\end{array}$ & $100 \%$ & $0 \%$ & $0 \%$ & $0 \%$ \\
\hline 9. & $\begin{array}{l}\text { The big book media } \\
\text { is presented in the } \\
\text { form of a story book } \\
\text { which is designed } \\
\text { using pictures so } \\
\text { that students do not } \\
\text { feel bored when }\end{array}$ & $100 \%$ & $0 \%$ & $0 \%$ & $0 \%$ \\
\hline
\end{tabular}




\begin{tabular}{|l|l|l|l|l|l|}
\hline & reading activities & & & & \\
\hline 10. & $\begin{array}{l}\text { The development of } \\
\text { the big book media } \\
\text { is used for students } \\
\text { as an insight into } \\
\text { activities to support } \\
\text { the literacy } \\
\text { movement. }\end{array}$ & & & & \\
\hline
\end{tabular}

Table I shows that in average teachers strongly agree with the indicator of the big book media needs in the mother tongue which is a local solution in the literacy movement.

The results of this interview guide analysis provide an overview of the need for big book media in mother tongue that will be developed. In general, the teachers of Inpres Sambori Elementary School, Lambitu District strongly agree with development research were at first the average student in literacy was very low and there were still many who did not understand the content of the story or the content of the reading, therefore we researchers aim to present new innovations so that all students able to understand the content of the reading that is read by presenting the big book media in mother tongue which is polished with a story that is interpreted in the Bima language and a display that will make students interested in reading.

\section{TABLE II. INTERVIEW QUESTION}

\begin{tabular}{|l|}
\hline Question: \\
\hline 1. What is your understanding of literacy activities for big book \\
media? \\
2. Have you ever used the big book media in any literacy activities? \\
3. What learning resources do you use in literacy activities? \\
4. Do you have difficulty doing literacy activities? \\
5. Is the story collection book that you use is appropriate to reading \\
activities in applying literacy? \\
6. How do students respond to the big book media? \\
7. Do you agree if the researcher develops the big book media in \\
mother tongue as a local solution to support the literacy \\
movement?
\end{tabular}

Validation: Content, Language, and Graphics

The data needed to determine the validity of the big book media in are the content and the language presented in the Big Book media. The content and language were validated by Mrs. Siti Aminah, M.Pd, an expert in Indonesian language and literature education at the Al-Azhar Mataram Islamic University, and by Mrs. Mahani, S.Pd, a teacher of Local Content subject. Data from the validation by 1 and 2 .

TABLE III. VALIDATION DATA

\begin{tabular}{|c|c|c|c|c|c|}
\hline \multirow{2}{*}{ No. } & \multirow[t]{2}{*}{ Aspects } & \multicolumn{4}{|c|}{ Score } \\
\hline & & 4 & 3 & 2 & $\mathbf{1}$ \\
\hline \multirow[t]{5}{*}{ A. } & $\begin{array}{l}\text { Suitability of the Description of the Contents } \\
\text { of the Story }\end{array}$ & & \multirow{2}{*}{$\checkmark$} & & \\
\hline & $\begin{array}{l}\text { 1. The contents of the story contain } \\
\text { character values }\end{array}$ & & & & \\
\hline & $\begin{array}{l}\text { 2. The content of the story helps students } \\
\text { understand the story line }\end{array}$ & & $\checkmark$ & & \\
\hline & 3. $\quad$ Have a simple story line & & $\checkmark$ & & \\
\hline & $\begin{array}{l}\text { 4. Information content according to the } \\
\text { age of the reader }\end{array}$ & & $\checkmark$ & & \\
\hline
\end{tabular}

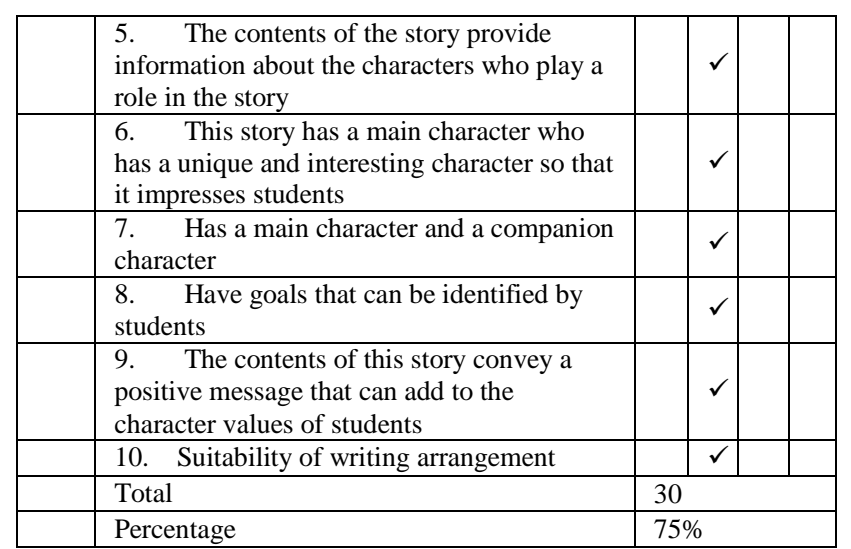

From the results of the analysis of content and language experts in the mother tongue big book media as a local solution to support the literacy movement, it is known that based on the analysis of the content expert validator assessment, namely one of the lecturers of Indonesian language and literature education at Al-Azhar Mataram Islamic University and local language local content subject teachers can It was concluded that the developed big book media got a validator rating percentage of $75 \%$ which indicates that the big book media is valid and can be implemented with a few revisions. Based on the analysis of the evaluation of the Bima and Indonesian linguist validator, it can be concluded that the developed big book media got a validator rating percentage of $75 \%$ which indicates that the big book media is valid and can be implemented with a little revision.

\section{Graphic Expert Validation}

Based on the analysis of the assessment of the graphical expert validator, namely one of the information technology education lecturers at STKIP Taman Siswa, namely Mr. Ilyas, S.Kom., M.Pd. The developed big book media can be concluded that the percentage of validators is $75 \%$, indicating that the big book media is valid and can be implemented with a few revisions.

\section{Student Response Questionnaire Analysis}

From the results of the student response questionnaire data, it is known that students of Inpres Sambori Elementary School, Lambitu District, (1) $82 \%$ strongly agree that literacy activities use big book media and do not make it difficult for them, (2) $85 \%$ agree that the language used in the big book media is easy to understand, (3) $91 \%$ strongly agree that big book media can improve their reading skills, (4) $80 \%$ agree that big book media increases my reading motivation, (5) 94\% strongly agrees that big book media is easy to use in the process of reading activities, (6) $97 \%$ agree that the contents of the big book media stories are easy to understand, (7) $100 \%$ strongly agree that the stories submitted in the big book media are very good, (8) $82 \%$ agree that the images in the big book media make it easier for me to understand the contents of the stories, (9) $100 \%$ strongly agree with the message in the big book media according to the content of the stories they read, and (10) 100\% strongly agree that the big book media is very practical and easy to read. The results of this student response questionnaire analysis provide an overview of students' responses to the mother tongue big book media as a local solution to support literacy being 
developed. In general, students showed a positive response to the development of the big book media that had been implemented.

\section{Product Revision}

Product revision is tentative, meaning that it can be done or not from the results of the analysis of the big book media assessment by an expert validator of content, language, and graphic presentation, some aspects indicate that the draft big book media needs revision.

\section{TABLE IV. THE REVISED AND UNREVISED PICTURES}

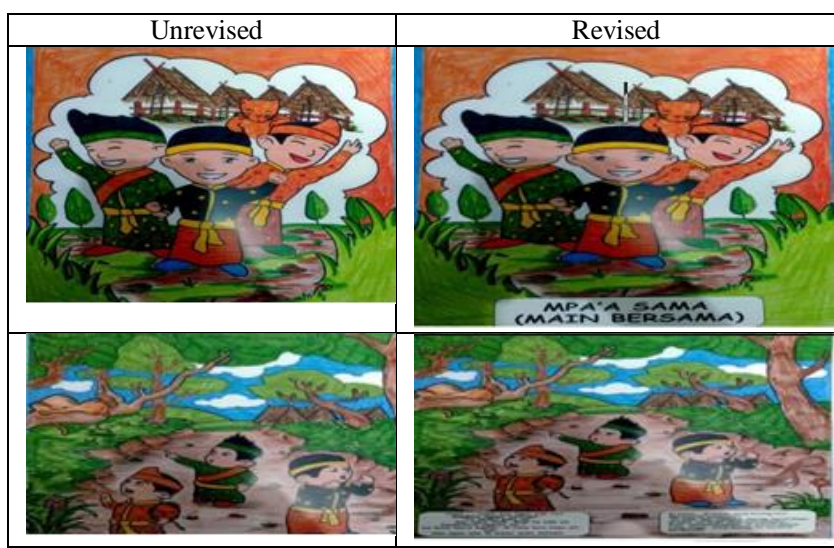

This revision was made to make the product more effective, efficient, and attractive. This is so that the big book media developed by researchers can be easily accepted by children. The big book media developed was revised based on the stages described in the product revision table, this was supported by development experts. Thus, this big book media can be used as a medium for local solutions to increase the literacy movement of students at Inpres Sambori Elementary School, Lambitu District, Bima Regency. The following is a presentation of the image that has been revised by the researcher:

\section{Final Product Description}

The resulting product is big book media in mother tongue that contains stories according to the student's ability level. This big book media is entitled Mpa'a Sama. The products developed to refer to (1) the content of big book media, (2) the presentation system which consists of the initial, core, and final / closing parts. (3) the use of language developed using a variety of formal and communicative languages and easy for students to understand to make reading easier. and (4) the graphic/appearance of themedia big book gives an attractive impression so that students are motivated to read.

Media Big book is a large book equipped with large text and images that make it easier for children to observe every letter or symbol contained in the book, Big book also equipped with colorful pictures and a simple and easy-tounderstand storyline for students. The specialty of big book is that it provides opportunities for students to develop what low-grade students like so that it can increase student motivation and activeness in increasing the literacy movement at Inpres Sambori Elementary School.
The Development Big Book Media Mother Languages a Local Solution to Improve Student Literacy Movement at Inpres Sambori Elementary School, Lambitu District, Bima Regency has passed the product evaluation stage, both limited feasibility tests from content experts, language and graphic experts, as well as product trials which include initial field testing, The main field test and field test were expanded, the big book media product as a result of the development was worthy of being a final product that could be practiced to increase student reading interest. Based on the findings in this study, it was revealed that the literacy learning process using big book media greatly facilitates students in understanding literacy material, is fun, interesting, motivates students and activates students in learning.

Literacy movement in stages by considering the readiness of each school. This readiness includes readiness of physical capacity, the readiness of school members and readiness of systems and other supports. To ensure that the literacy movement takes place in the long term, it is carried out in three stages, namely the habituation stage, the development stage and the learning stage. The activity of implementing the literacy movement habituation at this stage aims to foster children's interest in reading and reading activities, improve movement skills through reading books and improve movement skills in all places including 1) literacy skills, 2) what is the focus and the principle of activity in the habituation stage. Fostering a literacy movement is the same as making a child open their horizons in reading, especially with the presence big book in mother tongue will help children quickly understand the content of the reading and be able to adapt to the contents of the story in the media, therefore the literacy movement is the initial movement to produce culture conscious to be lifelong learning.

After conducting a field test, the product big book made it very easy for students to learn, this was because the big book media design immediately interpreted the local language into the national language, and images were displayed that made the students like it. An example of previous research [1], Early Reading Skills through Big Book Media for Class IB SDN Students. It is intended to open to see the picture directly they read what is in the picture, thus currently students at Inpres Sambori Elementary School have increased interest in reading.

\section{CONCLUSION}

The study has shown that the Development Big Book Media in Mother Languages a Local Solution for Increasing the Student Literacy Movement at Inpres Sambori Elementary School, Lambitu District, Bima Regency, has passed the product evaluation stage, both the limited feasibility test of content, language and graphic experts, as well as product trials which include initial field tests, main field trials and expanded field trials, the big book media product resulting from the development is worthy of being a final product that can be practiced to increase students' reading interest. The learning process of students can improve the literacy movement by using the Big Book in their mother tongue, which greatly facilitates students in understanding literacy material as well as being fun, interesting, motivating students and activating students in learning. Suggestions in the development big book media 
need a policy from the Regional Government through the education and culture office of Bima Regency to design large media based on local wisdom, this is important to do to increase the reading interest of SDN students in Bima Regency.

\section{REFERENCES}

[1] Yuniati. Keterampilan Membaca Permulaan Melalui Media Big Book Siswa Kelas IB SDN Mangiran Kecamatan Srandakan, Universitas Negeri Yogyakarta, 2014

[2] Faizal, and D. Utama, Panduan Gerakan Literasi Sekolah Di Sekolah Dasar. Jakarta: Direktorat Pembinaan Sekolah Dasa, 2016.

[3] USAID, Buku Sumber untuk Dosen LPTK: Pembelajaran Literasi Kelas Awal SD/MI di LPTK. Jakarta: USAID, 2014.

[4] N. Fatimah, "Pengembangan buku cerita rakyat bima berbasis kearifan lokal", J. Ilmiah Nosi Vol. 5, No. 3, Februari 2017.

[5] P. Setyosari, Metode Penelitian Pendidikan dan Pengembangan. Jakarta: Kencana Prenada Media Group, 2015.

[6] Sugiyono, Metode Penelitian Pendidikan Kuantitatif, Kualitatif, dan R\&D, Bandung: Alvabeta, 2015. 